\title{
Evaluation of Pansy Varieties as Bedding Plants to Select the Best-of-Class for Florida ${ }^{1}$
}

\section{R.O. Kelly, Z. Deng, and B.K. Harbaugh ${ }^{2}$}

Pansy (from the French word pensee, meaning thought; folk-name: heartsease) is one of the oldest garden flowers. John Parkinson mentions its use in 1629. Records indicate their use in medicine by the Greeks in the $4^{\text {th }}$ century BC. Hybrid pansies were created from violas, a large genus of 500 species. It is believed that a European observed a plant similar to viola found in open, sunlit areas and called it a wild pansy. William Thompson, an English gardener in the early $19^{\text {th }}$ century, made crosses with Viola tricolor, $V$. lutea and a blue flowered species thought to be of Russian origin. Thompson is credited with discovering the cross that began the new interspecific hybrid species $V$. x wittrockiana Gams.

Florida was fifth in the United States for the number of potted pansies/violas produced, and their wholesale value reached $\$ 2.0$ million in 2003 (USDA, Floriculture Crops 2003 Summary). Pansy varieties are developed outside Florida (west or north U.S., Japan, or Europe) where climate and soil are very different from Florida's. Seed companies release new varieties yearly, so timely evaluations are critical to provide Florida flower growers, landscapers and home gardeners with performance data to help them make variety selection decisions.

\section{Field trials and evaluations}

Four trials were conducted between Dec. 2000 and Mar. 2004 at the University of Florida's Gulf Coast Research and Education Center in Bradenton. A total of 210 pansy varieties were evaluated in a best-of-class trial system in which varieties are grouped into color classes and the best performer in each class is selected. Best-of-class varieties are subsequently used for comparison to test all new entries from seed companies. A new entry with a higher overall performance rating than the existing best-of-class variety becomes the new best-of-class selection for that class.

Raised flower beds were formed of native soil, fumigated, and covered with white plastic mulch. Young plants were grown from seeds in flats with 1.5 x 1.5 x 2.5 inch cells in a greenhouse or screenhouse, and planted in multiple plots randomly placed in their color class in two fields, one field sprayed with pesticide on demand to evaluate plant and flower quality, and the other field unsprayed to evaluate pest damage. Uniform and sufficient nutrients (Osmocote Plus) and moisture were provided to each plant to allow for outstanding growth and flowering.

1. This document is ENH1031, one of a series of the Environmental Horticulture Department, Florida Cooperative Extension Service, Institute of Food and Agricultural Sciences, University of Florida. Original publication date August 1, 2005. Visit the EDIS Web Site at http://edis.ifas.ufl.edu.

2. R.O. Kelly, coordinator/variety trial research; Z. Deng, assistant professor; and B.K. Harbaugh, professor, Environmental Horticulture, Gulf Coast Research and Education Center, Cooperative Extension Service, IFAS, University of Florida, Gainesville, 32611.

The Institute of Food and Agricultural Sciences (IFAS) is an Equal Opportunity Institution authorized to provide research, educational information and other services only to individuals and institutions that function with non-discrimination with respect to race, creed, color, religion, age, disability, sex, sexual orientation, marital status, national origin, political opinions or affiliations. U.S. Department of Agriculture, Cooperative Extension Service, University of Florida, IFAS, Florida A. \& M. University Cooperative Extension Program, and Boards of County Commissioners Cooperating. Larry Arrington, Dean 
Ratings for foliage and flowers ranged from 1 to 7 , with a 7 rating for foliage or flowers free of any defects such as lodging, lack of foliage or flower uniformity or quality, disease or pest damage; a 4 for foliage or flowers with some problems, but still acceptable; while a 1 rating was for poor and unacceptable plants. Multiple (3 to 4 ) ratings were taken over time in both fields and averaged to produce an overall performance rating. We believe that the overall performance ratings represent the best view of garden performance for each variety in its class over the entire season, and therefore, this overall rating was used to select each best-of-class variety. Varieties with an overall performance rating $\geq 5.5$ were considered as outstanding, 5.0 - 5.4 as good, $4.0-4.9$ as fair and $<4.0$ as poor.

\section{Best-of-class}

Current best-of-class varieties (Table 1) considered more suitable for the garden, based on an average of the combined foliage and flower quality ratings $\geq 4.5$ and an overall performance rating $>5.0$ are 'Accord/Banner Black Beauty', 'Baby Bingo Denim', 'Baby Bingo Lavender Blue', 'Bingo Clear Purple', 'Bingo Red And Yellow', 'Dynamite Wine Flash', 'Iona Purple' and 'Yellow With Blotch', 'Karma Red Blotch', 'Majestic Giants II Marina Shades', 'Nature Beacon', 'Nature Blue', 'Nature Ocean', 'Nature Pink Shades', 'Nature Rose with Blotch', 'Nature White', 'Nature Yellow', 'Panola Clear Mixture', 'Panola Orange', 'Panola Purple With Face', 'Panola Yellow With Blotch', 'Whiskers Purple White', and 'Whiskers Yellow'.

\section{Pests observed on pansies}

Most of the common pansy pests in the unsprayed field only caused minor damage; however, thrips (Frankliniella sp.) (Figure 1) damage to flowers always lowered ratings. Effects were selective, with more damage symptoms appearing on larger, dark and strongly colored flowers across the spectrum. Scarring was more concentrated on the first cap petal, with less on the second petal, wings and lip; white, black and pastel colors showed few if any symptoms.

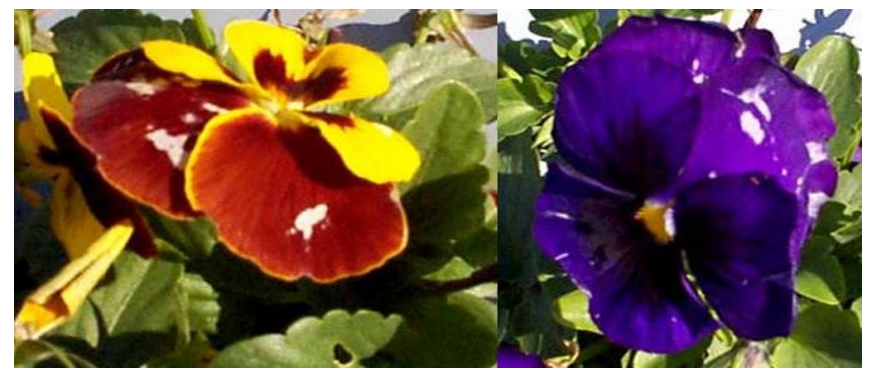

Figure 1. Thrips (Frankliniella sp.) damage to flower petals. Credits: R.O. Kelly/GCREC

Graymold (Botrytis sp.) thrives here between January and April. In mid February, sun-drenched soils meet cold air to produce morning fogs, condensing on flowers to create an environment ideal for graymold sporulation (Figures 2 and 3). Larger flowers offer more tissue for infestation. As the disease develops, affected flowers bow down and inoculate leaves with massive doses of spores (Figure 4). Leaves develop large tan lesions with darker concentric rings that, may result in unsightly plants. In our observations, more smaller-flowered varieties performed better than large-flowered varieties.

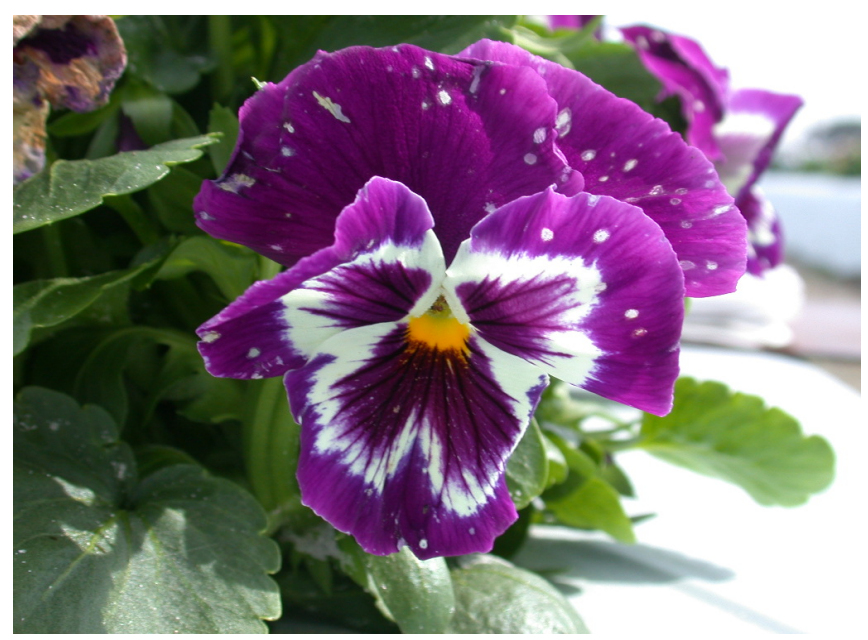

Figure 2. Early stages of graymold (Botrytis sp.) forming the circular lesions on flower petals. Credits: R.O. Kelly/GCREC

Powdery mildew (Figure 5) first appeared in the 2003-3004 trials and affected foliage. Sphaerotheca macularis, S. fuliginea and $S$. violae have been isolated from Viola species in the U. S., while only $S$. macularis was reported in Florida. Foliage disease ratings ranged from high to low. 


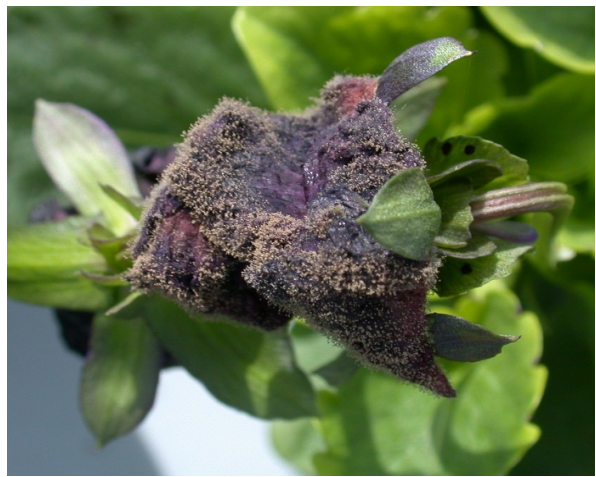

Figure 3. Flower severely infested with graymold. Credits: R.O. Kelly/GCREC

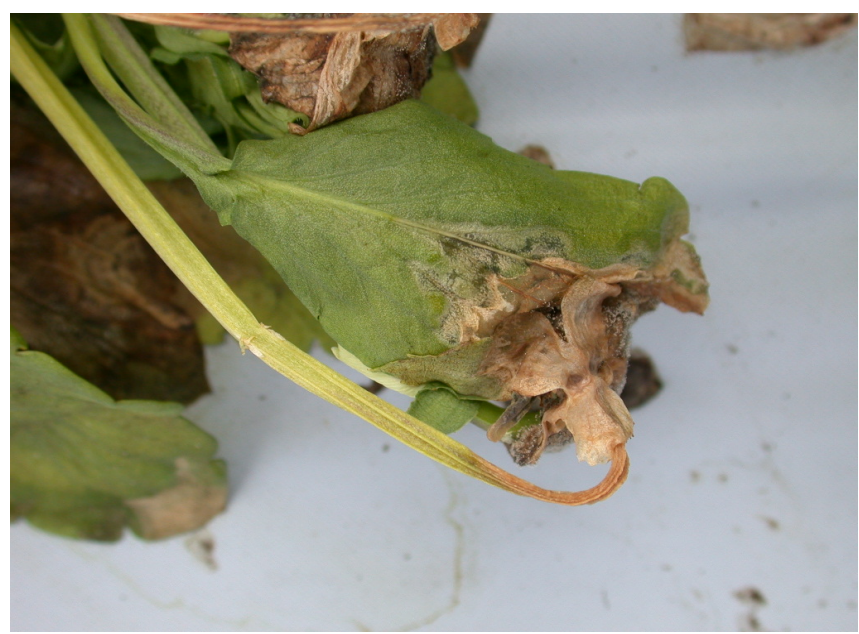

Figure 4. Flower transferring graymold directly to foliage. Credits: R.O. Kelly/GCREC

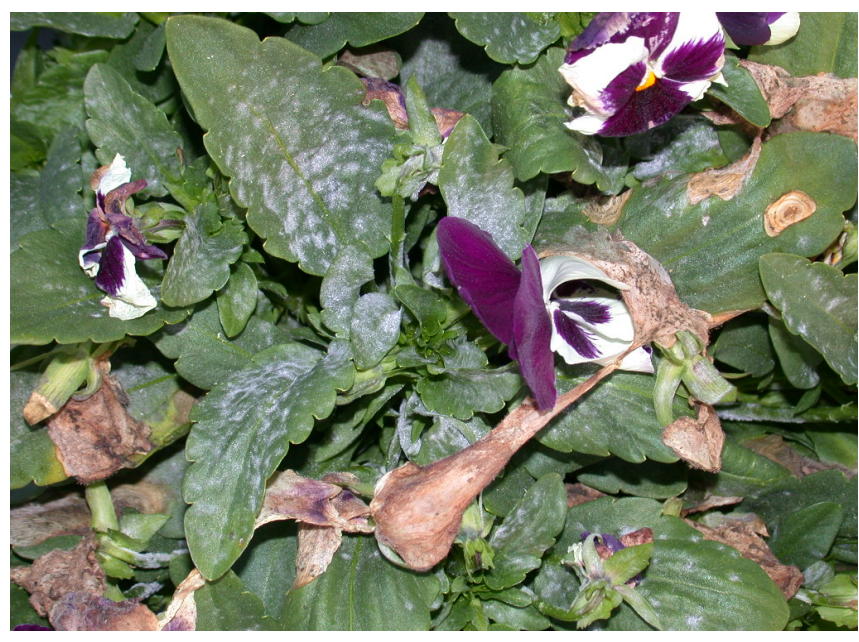

Figure 5. Powdery mildew (Sphaerotheca macularis) Credits: R.O. Kelly/GCREC

\section{Additional information}

Visit the seed-propagated bedding plant variety trials at http://vtgcrec.ifas.ufl.edu for detailed information on plant height, width, days to flower, flower divergence, flower size and individual ratings, as well as plot pictures during the season and more flower pictures for all the pansy varieties evaluated. To view and print photos of the Best-of-Class varieties follow this link: http://vtgcrec.ifas.ufl.edu/PansyVTphotos.pdf.

\section{Note}

The information in this report is a summary of experimental results and does not provide recommendations for crop production. Where trade names are used, no discrimination is intended or endorsement implied.

${ }^{1}$ Our flower descriptions: the two top petals $=$ cap petals; two lateral petals = wing petals; bottom petal $=$ lip; the lip + wings $=$ face . 


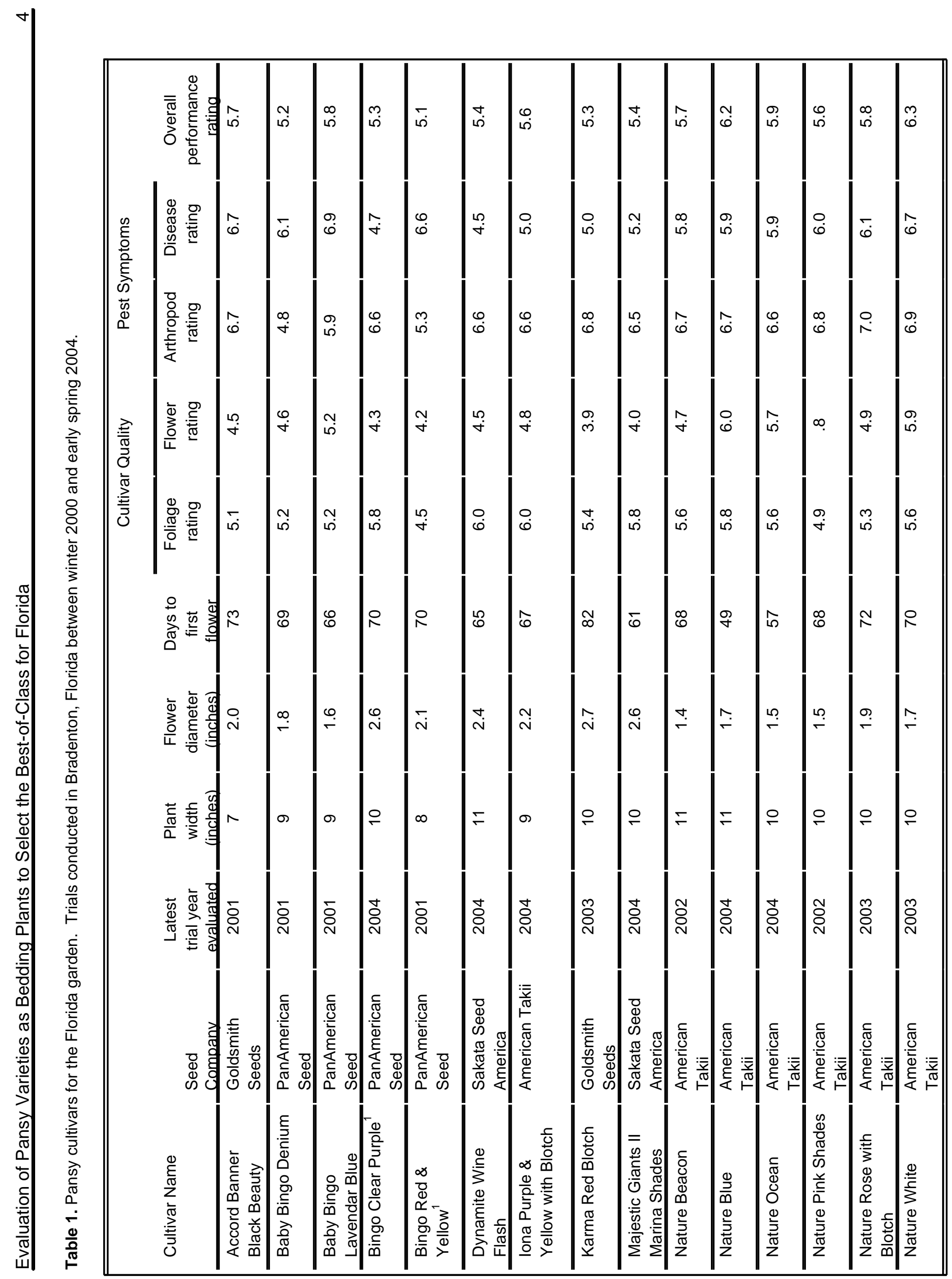




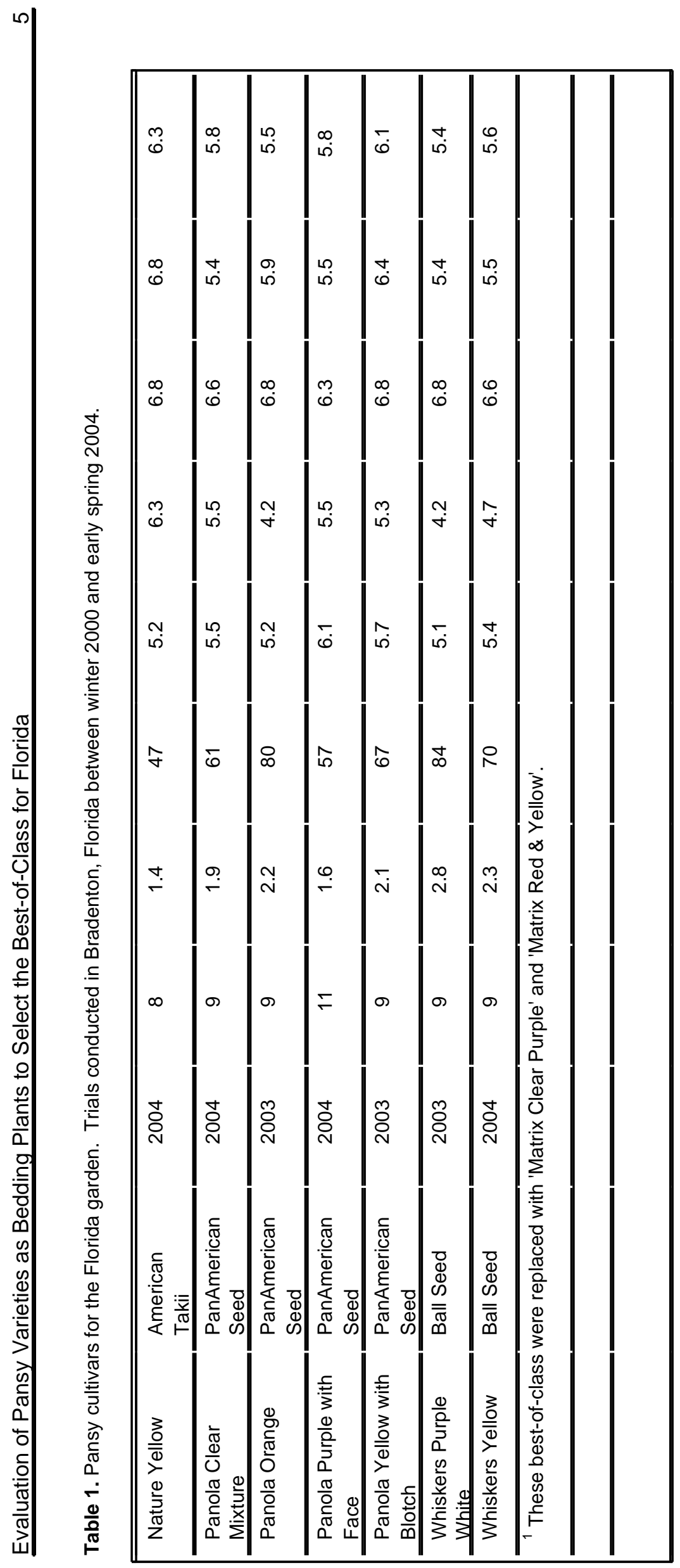

